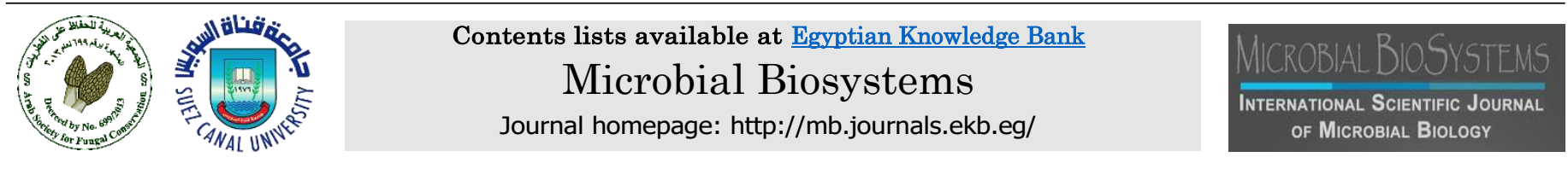

\title{
An updated checklist of the myxomycetes in the Maltese islands - An overview of an ongoing research
}

\section{Stephen Mifsud*}

EcoGozo Directorate, Ministry for Gozo, Victoria, Gozo, Malta..

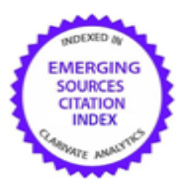

\begin{tabular}{l} 
ARTICLE INFO \\
\hline Article history \\
Received 18 October 2020 \\
Received revised 4 December \\
Accepted 6 December 2020 \\
Available online 8 December \\
○ Mifsud, 2020 \\
Corresponding Editor: \\
Mouchacca J \\
Balbool BA \\
Abdel-Azeem AM \\
Keywords \\
Slime moulds \\
checklist \\
Malta \\
Central Mediterranean region
\end{tabular}

\begin{abstract}
Myxomycetes are minuscule cryptogamic saprotrophs of decaying vegetative matter, but which also feed and therefore control soil bacteria, microfungi or fungal spores. Yet, their role is not much valued in conservation protocols, and they are not frequently included in red lists. Their study in the Maltese Islands commenced only in the late 20th century by Michael Briffa, where he published 74 records. This account amalgamates the previously published records, revised to their current taxonomy and classification, with new records collected in this research between 2014-2020. The resulting checklist of 96 myxomycetes occurring in the Maltese Islands is here provided. The location, date and host of the first record of each species are given in this annotated checklist. The 22 new records are members of the genera Cribraria, Lycogala, Echinostelium, Perichaena, Trichia, Badhamia, Craterium, Fuligo, Physarum, Diderma, Didymium and Mucilago. This ongoing study on the slime moulds of the Maltese Islands aims to collect, photograph and identify as many specimens as possible so a better represented and updated inventory is compiled. From the past records, experience and fieldwork gained in this research, the myxomycetes that are considered rare or threatened are identified for possible inclusion in a national Red Data List of cryptogams. Moreover, collections currently deposited at the author's Fungarium may be used to revive populations (e.g. in moist chambers) that are very rare and hence may be used for the conservation of native slime moulds. Finally, this work helps further students and international experts to comprehend which myxomycetes are currently recorded in the Maltese Islands.
\end{abstract}

Published by Arab Society for Fungal Conservation

\section{Introduction}

The classification of Myxomycetes, or as commonly known, slime moulds, have for a long-time baffled biologists and taxonomists mostly for their metamorphic life cycle. In the past, they have been variously classified as fungi, animals, or less frequently, as plants.

\footnotetext{
* Corresponding author

E-mail address: info@maltawildplants.com (Stephen Mifsud)
}

Myxomycetes undergo two completely different forms or phases within their life cycle, where initially they possess a protozoic phase in the form of a mucoid mobile mould known as a plasmodium. It is composed of an aggregate of flagellate amoeba and which, as a whole, it 
can travel slowly to short distances. When mature, the plasmodia develop into a dry fungal-like fruiting phase referred to as the myxocarp which often resembles a small gasteroid fungus (Martin and Alexopolos 1969; Poulain et al. 2011).

Indeed, in the 18th and the beginning of the 19thcentury, scientists considered slime moulds to be small species of gasteromycetes within the kingdom of fungi, and thus they have been studied mostly by mycologists. At last, Link (1833) was the first to classify slime moulds in an own group that he coined as Myxomycetes - literally meaning mucoid fungi (Martin and Alexopolos 1969; Stephenson and Schnitler 2017). Later on, other scientists insisted that they are fungi-like protozoans instead of fungi, and nowadays, their classification within the ameboid protozoa (the supergroup Amoebozoa) is accepted by most myxomycologists. They are currently grouped in their own infraphylum called Mycetozoa (= fungi animals). However, molecular data have still not settled the ancestral seating of the slime moulds within the Eukaryote domain (Stephenson and Schnittler 2017).

The pioneer botanists and naturalists that studied the Maltese natural history have covered a great part of the vegetative biodiversity, including many cryptogams growing in the Maltese Islands, namely the vascular flora, ferns, fungi (especially the microfungi), lichens and mosses (e.g. Grech Delicata 1853; Sommier and Caruana Gatto 1915; Saccardo 1911, 1914 and 1915; Borg 1927 amongst others). Unexplainably, however, myxomycetes have been neglected during this pioneer period. The first study was that of the late Michael Briffa, who published his findings during the very end of the 20th century. During the fieldwork he carried out between 1994 to 1997, Briffa (1998) recorded 71 taxa of slime moulds from the Maltese Islands. In a consequent update (Briffa et al. 2000), three new records had been added. The study of myxomycetes resumed by the present author resulted in several new records, four of which had already been reported (Mifsud 2017a, b).

This work aims to combine all the previously published records (Briffa and Mifsud op. cit.) with new records found by the author to provide an updated checklist of Myxogastria for the Maltese Islands using the latest classification according to Poulain et al. (2011). It is a part of an ongoing project to research local myxogastria, hopefully leading to some protection and conservation of some rare species, albeit slime moulds are often neglected at a legal level primarily of their minute size, and because they are neither pathogenic nor of ecological importance.

A complete (record) list of all published records and tentative attempts to determine which slime moulds are rare will follow this work. Moreover, several unidentified materials collected by the present author (and possibly by
Michael Briffa) will be investigated thoroughly in future work.

\section{Materials \& Methods}

The 78 published records of slime moulds from the Maltese islands - 71 in Briffa (1998); three in Briffa et al. (2000), two in Mifsud (2017a), and another two in Mifsud (2017b) - have been combined with 17 new records found by the author during the period 2014-2020. Their taxa have been revised according to the nomenclature of MycoBank (2020), which in turn are classified according to the International Code of Nomenclature for algae, fungi, and plants.

The identification of specimens was based on the gross morphology of the fruiting bodies in situ as well as by the microscopic analysis of the collected myxocarps using a high magnification of up to $\times 1000$ of a Carl Zeiss AxioLab light microscope mounted in water, $3 \% \mathrm{KOH}$ or mycological stains (namely $1 \%$ Congo Red and $1 \%$ Cotton Blue). Calibrated measurements up to a resolution of $0.1 \mathrm{um}$ could be taken using photomicrographs superimposed with a reticule's calibrated scale and with the software Pixemetre V5.1 by Alan Henriot.

Identification was quite successful using keys by Poulain et al. (2011) and Martin and Alexopolos (1969) amongst other keys found online, but occasionally, further clarifications where achieved from specific literature or consultation with experts on social media or online flora.

The resulting checklist only gives data about the first record of each species, and so it does not include information about all the material recorded or examined. Hence, this checklist is not suitable for distributional or other quantitative purposes. An annotated and more elaborate checklist is planned in the coming years. Each species is enumerated and their listing is given in order of classification according to Mycobank (2020), hence initiating the checklist with the order Protosteliales followed by Liceales, Echinostelliales, Trichiales, Physarales and Stemonitales and then the corresponding subsequent families. Species are then sorted alphabetically. For each entry (species) the following information is given: species name, author citation, reference mycobank number, locality and date of the first record, habitat or host where it was found growing and the first publication unless it is a new record first published in this work. For the last datum, MB stands for Michael Briffa and SM for Stephen Mifsud, for example "MB, 1998" corresponds to the cited reference 'Briffa (1998)'. The specimens determined by Briffa (1998) and Briffa et al. (2000) has not been analysed or verified in this account, but since a majority of Briffa's material was at that time already been examined and determined by a number of experts (Briffa 1998) most of 
them are here assumed to be reliable. Images of some of the new records are given and captioned accordingly.

\section{Results}

An updated checklist of Mycetozoa

Phylum (Supergroup): Amoebozoa

Infraphylum: Mycetozoa

Class: PROTOSTELIOMYCETES

Order: Protosteliales

Family: Ceratiomyxaceae

1. Ceratiomyxa fruticulosa (O.F. Müll.) T. Macbr. [MB \#232106]

Maqluba (08-Oct-1996) - Dead branch of Ceratonia siliqua (MB, 1998).

Remark: Recent phylogeny suggest the exclusion of Ceratiomyxaceae from the Myxogastria, and hence making Mycetozoa a completely monophyletic group of five orders (Kretzschmar et al. 2015) morphologically bound by endogenic spore formation (Stephenson and Schnittler, 2017). At present, this species is retained within the checklist to include all taxa recorded in the past as myxomycetes

\section{Class: MYXOMYCETES (MYXOGASTRIA)}

Order: I. Liceales

Family: Liceaceae

2. Licea variabilis Schrad. [MB \#175383]

Qormi (06-Nov-1983) - Dead leaves of unknown species (MB, 1998).

Family: Cribrariaceae

3. Cribraria argillacea (Pers. ex J.F. Gmel.) Pers. [MB \#248562]

Buskett (28-Oct-1997) - Dead stump of Ceratonia siliqua (MB, 1998).

4. Cribraria cancellata (Batsch) Nann.-Bremek. [MB \#312279]

Ghajn il-kbira (30-Oct-1995) - Dead wood of Populus alba (MB, 1998).

5. Cribraria intricata Schrad. [MB \#148753]

Menzja Farm House (11-Nov-2019) - On decaying bark of Hibiscus rosa-sinensis in a private garden (new record).

6. Cribraria violacea $\operatorname{Rex~[MB~\# 242480]~}$

Ghajn il-kbira (27-Nov-1997) - Unidentified stem close to Ulmus canescens (MB, 1998).

Family: Reticulariaceae

7. Dictydiaethalium plumbeum (Schumach.) Rostaf. [MB \#119378]

11
Ghajn il-kbira (03-Feb-1997) - Unidentified dead branch (MB, 1998).

8. Enteridium splendens (Morgan) T. Macbr. [MB \#222384]

Maqluba (08-Oct-1996) - Dead branch of Ceratonia siliqua (MB, 1998).

9. Lycogala confusum Nann.-Bremek. ex Ing [MB \#450203]

Xewkija (Ulysses Garden) (02-Dec-2016) - Animal bedding and manure dumped on soil (SM, 2017b).

10. Lycogala epidendrum (L.) Fr. [MB \#205910]

Ballut tal-Wardija (29-Sep-1995) - Fallen branches of Quercus ilex (MB, 1998).

11. Lycogala exiguum Morgan [MB \#212013]

Wied il-Lunzjata (Gozo) (29-Oct-2020) - On a piece of wood of some old trashed furniture (new record).

12. Lycogala flavofuscum (Ehrenb.) Rostaf. [MB \#356737] Wied il-Luq (01-Oct-1985) - Living trunk of Fraxinus angustifolia (MB, 1998).

13. Reticularia jurana Meyl. [MB \#189345]

Imgiebah (24-Oct-1996) - Dead branch of Ceratonia siliqua (MB, 1998).

14. Tubifera microsperma (Berk. \& M.A. Curtis) G.W. Martin [MB \#371707]

Buskett (28-Oct-1997) - Dead stump of Ceratonia siliqua (MB, 1998).

Order: II. Echinostelliales

Family: Echinostellaceae

15. Echinostelium colliculosum K.D. Whitney \& H.W. Keller [MB \#113769]

originally collected (n.loc.) and determined by H. Mueller and subsequently grown in moist chamber (01-May-1995) by Michael Briffa (MB, 1998).

16. Echinostelium minutum de Bary [MB \#184024] Buskett (31/11/2017) - Dead twigs of Populus alba (new record).

Order: III. Trichiales

Family: Arcyriaceae

17. Arcyria cinerea (Bull.) Pers. [MB \#174952]

Buskett (05-Jan-1996) - Hymenial surface of Ganoderma lucidum (MB, 1998). 
18. Arcyria denudata (L.) Wettst. [MB \#120316]

Ghajn il-kbira (10-Nov-1995) - Dead remains of Prunus sp. (MB, 1998).

19. Arcyria incarnata (Pers. ex J.F. Gmel.) [MB \#234244] Imgiebah (24-Oct-1996) - Dead branch of Quercus ilex (MB, 1998).

20. Arcyria insignis Kalchbr. \& Cooke [MB \#162948]

Maqluba (08-Oct-1996) - Dead bark of Laurus nobilis (MB, 1998).

21. Arcyria major (G. Lister) Ing [MB \#326444]

Imgiebah (04-Feb-1999) - Dead branch of Quercus ilex (MB, 2000).

22. Arcyria minuta Buchet [MB \#253365]

Ballut tal-Wardija (23-Sep-1996) - Dead branch of Quercus ilex (MB, 1998).

23. Arcyria nutans (Bull.) Grev. [MB \#245049]

Wied il-Lunzjata (Gozo) (09-Oct-2020) - Dead branch of Ceratonia siliqua (new record).

24. Arcyria obvelata (Oeder) Onsberg [MB \#308918]

Maqluba (08-Oct-1996) - Dead branch of Ceratonia siliqua (MB, 1998).

25. Arcyria oerstedii Rostaf. [MB \#141739]

Ghajn il-kbira (10-Nov-1995) - Decaying wood of Prunus sp. (MB, 1998).

26. Arcyria pomiformis (Leers) Rostaf. [MB \#145668]

Ballut tal-Wardija (18-Dec-1995) - On dead wood (MB, 1998).

27. Metatrichia vesparium (Batsch) Nann.-Bremek. [MB \#317607]

Ghajn il-kbira (23-Jan-1995) - Dead wood of Populus alba (MB, 1998).

28. Perichaena chrysosperma (Curr.) Lister [MB \#118849] Wied 1-Imgarr (Gozo) (14-Feb-2019) - Bark of Ailanthus altissima (new record).

29. Perichaena corticalis (Batsch) Rostaf. [MB \#148902] Buskett (16-Oct-1995) - Unknown fallen trunk (MB, 1998).

30. Perichaena depressa Lib. [MB \#149011]

Ghajn il-kbira (23-Mar-1996) - Dead wood of unknown species (MB, 1998).
31. Perichaena vermicularis (Schwein.) Rostaf. [MB \#247811]

Wied Imgarr ix-Xini (10-Dec-2017) - Dead twig of Rubus ulmifolius (new record).

Family: Trichiaceae

32. Trichia affinis de Bary [MB \#185554]

Wied Bingemma (15-Feb-2015) - Dead branch of Olea europaea (SM, 2017a).

33. Trichia contorta G.H. Otth [MB \#147103]

Ghajn il-kbira (23-Jan-1995) - Dead wood of Populus alba (MB, 1998).

34. Trichia contorta var. inconspicua (Rostaf.) Lister [MB \#139012]

Ghajn il-kbira (23-Jan-1995) - Dead wood of Populus alba (MB, 1998).

35. Trichia decipiens (Pers.) T. Macbr. [MB \#164198] Ghajn il-kbira (23-Mar-1996) - Dead wood of Populus alba (MB, 1998).

36. Trichia lutescens (Lister) Lister [MB \#174192] Ballut tal-Wardija (16-Jan-1996) - Dead branch of Quercus ilex (MB, 1998).

37. Trichia persimilis $\mathrm{P}$. Karst. [MB \#178360]

Ballut tal-Wardija (23-Sep-1996) - Dead branch of Olea europaea (MB, 1998).

38. Trichia varia (Pers. ex J.F. Gmel.) Pers. [MB \#202729] Ghajn il-kbira (23-Mar-1996) - Dead wood of unknown species (MB, 1998).

Order: IV. Physarales

Family: Physaraceae

39. Badhamia foliicola Lister [MB \#238735]

Ballut tal-Wardija (18-Dec-1995) - Dead leaves of Ceratonia siliqua (MB, 1998).

40. Badhamia melanospora Speg. [MB \#248392]

Wied Rihana (Gozo) (11-Jan-2018) - Dead woody stems of unknown species (new record).

41. Badhamia panicea (Fr.) Rostaf [MB \#243848]

Wied Imgarr ix-Xini (07-Dec-2019) - Dead wood of Ceratonia siliqua (new record).

42. Badhamia utricularis (Bull.) Berk. [MB \#147913] Ghajn il-kbira (15-Nov-1994) - Dead branch of Prunus sp. (MB, 1998). 
43. Craterium aureonucleatum Nann.-Bremek. [MB \#329225]

Wied Biljun (Gozo) (31-Jan-2019) - Dead leaves of Ceratonia siliqua (new record).

44. Craterium aureum (Schumach.) Rostaf4. [MB \#181399]

Ballut tal-Wardija (13-Nov-1995) - Dead branch of Prunus sp. (MB, 1998).

45. Craterium leucocephalum (Pers. ex J.F. Gmel.) Ditmar [MB \#192765]

Imgiebah (16-Jan-1997) - Dead leaves of Quercus ilex (MB, 1998).

46. Craterium rubronodum Lister [MB \#181561]

Imgiebah (21-Nov-1997) - Leaf litter of Quercus ilex (MB, 1998).

47. Fuligo gyrosa (Rostaf.) E. Jahn [MB \#241604]

Wied Babu (13-Feb-1997) - Dead twig of Rubus ulmifolius (MB, 1998).

48. Fuligo intermedia T. Macbr. [MB \#314194]

Ballut tal-Wardija (23-Oct-2017) - Leaf litter of Pinus halepensis (new record).

49. Fuligo septica (L.) F.H. Wigg. var. flava (Pers.) Morgan [MB \#149977]

Buskett (30-Sep-2014) - Sticks and dry matter of herbaceous wild plants in fallow fields (new record).

50. Leocarpus fragilis (Dicks.) Rostaf. [MB \#207070] Imgiebah (23-Dec-1994) - Debris of Quercus ilex (MB, 1998).

51. Lignydium licheniforme (Szabó ex Schwein.) Kuntze [MB \#526918]

Wied Babu (17-Mar-1997) - Decaying legume of Ceratonia siliqua (MB, 1998).

52. Physarum album (Bull.) Chevall. [MB \#249444]

Wied il-Lunzjata (Gozo) (15-Jan-2019) - On bark of Ceratonia siliqua (new record).

53. Physarum bitectum G. Lister [MB \#434174]

Wied Babu (13-Feb-1997) - Dead wood of Ceratonia siliqua (MB, 1998).

54. Physarum bogoriense Racib. [MB \#162327]

Maqluba (01-Mar-1996) - Moss growing on dead wood (MB, 1998).
55. Physarum cinereum (Batsch) Pers. [MB \#166471] Imgiebah (10-Dec-1993) - Dead leaves of unknown species (MB, 1998).

56. Physarum compressum Alb. \& Schwein. [MB \#261574]

Wied Babu (13-Feb-1997) - Dead herbacious stem of unknown species (MB, 1998).

57. Physarum daamsii Nann.-Bremek. [MB \#320444]

Xewkija (Ulysses Garden) (02-Dec-2016) - Animal bedding and manure dumped on soil (SM, 2017b).

58. Physarum echinosporum Lister, J. [MB \#210888] Imgiebah (21-Nov-1997) - Dead wood of Quercus ilex (MB, 1998).

59. Physarum leucophaeum Fr. \& Palmquist [MB \#210916]

Ghajn il-kbira (28-Dec-1993) - Stump of Prunus sp. (MB, 1998).

60. Physarum perfectum M. Peck [MB \#237448]

Wied Babu (13-Feb-1997) - Dead leaves of Ceratonia siliqua (MB, 1998).

61. Physarum plicatum Nann.-Bremek. \& Y. Yamam. [MB \#134224]

Wied Imgarr ix-Xini (01-Dec-2019) - Dead leaves of Ceratonia siliqua (new record).

62. Physarum pusillum (Berk. \& M.A. Curtis) G. Lister [MB \#121249]

Wied Babu (17-Mar-1997) - Dead wood of Ceratonia siliqua (MB, 1998).

63. Physarum straminipes Lister [MB \#141039]

Xewkija (Ulysses Garden) (02-Dec-2016) - Animal bedding and manure dumped on soil (new record).

64. Physarum viride (Bull.) Pers. [MB \#239928]

Buskett (23-Mar-1996) - Dead wood of Carya illinoinensis (MB, 1998).

Family: Didymaceae

65. Diderma cingulatum Nann.-Bremek., [MB \#111418]

Wied Bingemma (12-Mar-2019) - On dead wood of Olea europaea (new record).

66. Diderma hemisphaericum (Bull.) Hornem. [MB \#120603]

Maqluba (10-Feb-1985) - Dead leaves of Ceratonia siliqua (MB, 1998). 
67. Diderma spumarioides (Fr. \& Palmquist) Fr. [MB \#214417]

Ballut tal-Wardija (17-Jan-1997) - Herbacious stem of unknown origin (MB, 1998).

68. Didymium clavus (Alb. \& Schwein.) Rabenh. [MB \#160185]

Ballut tal-Wardija (17-Jan-1997) - Dead leaves of unknown species (MB, 1998).

69. Didymium bahiense var. europaeum Nann.-Bremek. [MB \#355747]

Wied Mgarr ix-Xini (14-Nov-2020) - Petiole of Acanthus mollis and herbaceous leaf litter in a damp valley bed (new record).

70. Didymium difforme (Pers.) Gray [MB \#176195]

Ghajn il-kbira (12-Feb-1996) - Dead leaves of Populus alba (MB, 1998).

71. Didymium iridis (Ditmar) Fr. [MB \#157402]

Wied Babu (20-Feb-1997) - Decaying legume of Ceratonia siliqua (MB, 1998).

72. Didymium leucopus (Link) Fr. [MB \#168424]

Ballut tal-Wardija (25-Oct-1995) - Dead leaves of unknown species (MB, 1998).

73. Didymium macrospermum Rostaf. [MB \#244877]

Wied Bingemma (12-Mar-2019) - Leaf litter of Olea europaea (new record).

74. Didymium melanospermum (Pers.) T. Macbr. [MB \#122848]

Wied Babu (20-Feb-1997) - Dead leaves of Ceratonia siliqua (MB, 1998).

75. Didymium melleum Berkeley \& Broome [MB \#239849] Ballut tal-Wardija (13-Nov-1995) - Dead leaves of Quercus ilex (MB, 1998).

76. Didymium minus (Lister) Morgan [MB \#250167] Ghajn il-kbira (23-Mar-1996) - Dead leaves of Eriobotrya japonica (MB, 1998).

77. Didymium nigripes (Link) Fr. [MB \#242247]

Ghajn il-kbira (02-Oct-1995) - Dead leaves of unknown species (MB, 1998).

78. Didymium quitense (Pat.) Torrend [MB \#247096] Maqluba (19-Feb-1999) - Dead wood of Punica granatum (MB, 1998). Remark: It was reported again from same locality on leaf litter of Ceratonia siliqua (Briffa et al. 2000)

79. Didymium squamulosum (Alb. \& Schwein.) Fr. \& Palmquist [MB \#181562]

Ballut tal-Wardija (13-Nov-1995) - Dead leaves of Ceratonia siliqua (MB, 1998).

80. Didymium trachysporum G. Lister [MB \#280481]

Maqluba (17-Mar-1997) - Dead wood of Laurus nobilis (MB, 1998).

81. Didymium verrucisporum A.L. Welden [MB \#544182] Wied Imgarr ix-Xini (07-Dec-2019) - Decaying legume of Ceratonia siliqua (new record).

82. Mucilago crustacea P. Micheli ex F.H. Wigg. [MB \#434180]

Munxar (10-Jan-2016) - Grassy weeds in a public garden (SM, 2017a).

\section{Class: DICTYOSTELIOMYCETES}

Order: V. Stemonitales

Family: Comatrichaceae

83. Comatricha anomala Rammeloo [MB \#311564]

Ballut tal-Wardija (27-Aug-1997) - Dead wood of Quercus ilex (MB, 1998).

84. Comatricha laxa Rostaf. [MB \#185323]

Wied Babu (29-Sep-1997) - Dead wood of Ceratonia siliqua (MB, 2000).

85. Comatricha nigra (Pers. ex J.F. Gmel.) J. Schröt [MB \#188390]

Ghajn il-kbira (06-Feb-1992) - Stump of Prunus sp. (MB, 1998).

86. Comatricha tenerrima (Berk. \& M.A. Curtis) G. Lister [MB \#279965]

Ghajn il-kbira (06-Nov-1997) - Stem of Acanthus mollis (MB, 1998).

Family: Stemonitaceae

87. Diachea leucopodia (Bull.) Rostaf. [MB \#120783]

Imgiebah (10-Jan-1985) - Leaves of Ceratonia siliqua (MB, 1998).

88. Enerthenema papillatum (Pers.) Rostaf. [MB \#249215] Maqluba (08-Oct-1996) - Dead branch of Ceratonia siliqua (MB, 1998).

89. Lamproderma scintillans (Berk. \& Broome) Morgan [MB \#121369] 
Ghajn il-kbira (06-Nov-1997) - Twig and leaf of Hedera helix (MB, 1998).

90. Stemonitis flavogenita E. Jahn [MB \#120472]

Ghajn il-kbira (02-Oct-1995) - Dead wood of Populus alba (MB, 1998).

91. Stemonitis fusca Roth. [MB \#240909]

Wied Babu (13-Feb-1997) - Dead branch of Ceratonia siliqua (MB, 1998).

92. Stemonitis smithii T. Macbr. [MB \#222156]

Maqluba (08-Oct-1996) - Dead branch of Ceratonia siliqua (MB, 1998).

93. Stemonitis splendens Rostaf. [MB \#230930]

Buskett (10-Nov-1994) - Fallen branches of Carya illinoinensis (MB, 1998).

94. Stemonitis virginiensis Rex [MB \#224407]

Maqluba (01-Mar-1996) - Dead wood of unknown species (MB, 1998).

95. Stemonitopsis hyperopta (Meyl.) Nann.-Bremek. [MB \#324056]

Wied Qirda (12-Feb-1998) - Dead wood of Ceratonia siliqua (MB, 2000).

96. Stemonitopsis typhina (F.H. Wigg.) Nann.-Bremek. [MB \#324060]

Ghajn il-kbira (23-Jan-1995) - Dead wood of Populus alba (MB, 1998).

\section{Known hosts of Slime Mould from the Maltese islands}

The living or dead material of several trees or plants that slime moulds have been recorded allow to give an insight of the most important host species of myxomycetes in Malta. This should provide further strength why these hosts, mostly native trees, should be protected, since they are direct natural habitats of myxomycetes. Table 1 lists the hosts and the species of slime moulds (using the reference number given in the checklist above) and the type of substrate they were found on (Table 1).

\section{Discussion}

At present, 93 species of Myxomycetes were recorded from the Maltese Islands. This is most likely an underrepresented number of the actual species present in Malta due to insufficient fieldwork. However, it is not expected to level up with neighbouring territories such as Sicily, Tunisia, or the Aegean islands. Apart from the smaller territorial size, the woody vegetation of the Maltese Islands is also restricted. Foremostly, the wooded and riparian areas are limited in size, and greatly disturbed by anthropogenic activities of an overpopulated country. In addition, the phanerophytes in these wooded habitats are not particularly diverse. Malta lacks mountainous habitats and wooded hills, whereas the valley is relatively smaller. Secondly, from a climatic point of view, the wet season is only six months long, typically October to March, and the coldest months can be attributed to mid-December, January and February only, all of which are shorter or less abundant from the aforementioned territories (https://www.climatestotravel.com). Hence, no myxomycetes are expected to be sighted in the dry months of April to September.

Nevertheless, these islands offer an interesting array of species from 11 families, the most dominant being limebearing families such as Physaraceae (26 species), Didymiaceae (18 species) and Arcyriaceae (15 species). Amongst the limeless families, Trichiaceae and Stemonitaceae are the most frequent, represented by seven and ten species, respectively (Fig.1)

Another relating problem is that the Myxomycetes, like several other cryptogams, are not appreciated or seriously protected in Malta. For example, the rehabilitation and conservation projects occurring at Buskett woodland, and recently at Wied il-Fiddien and Wied il-Qlejgha, incorporated the removal of herbaceous plants and the understory of the valley bed, including leaf litter, fallen branches and decaying organic matter (Fig. 2). Project leaders and environmental authorities considered this organic matter as dirt and debris that needs to be cleaned up for making way to aesthetically eye-pleasing pathways for the public. Huge losses in cryptogamic biodiversity are inevitable. 
Table 1 List of substrates that Myxomycetes were collected from Malta

\begin{tabular}{lll}
\hline Species & Substrate & Species code \\
\hline Ceratonia siliqua L. & Dead leaves & $39,43,60,61,66,74,78,79,87$ \\
& Dead wood or branches & $1,3,8,13,14,23,24,41,52,53$, \\
& & $62,84,88,91,92,95$ \\
Quercus ilex L. & Fallen Legumes & $51,71,81$ \\
& Dead leaves & $45,46,75$ \\
Populus alba L. & Dead twigs or wood & $10,19,21,22,36,50,83$ \\
& Dead leaves & $4,16,27,33,34,35,90,96$ \\
Olea europaea L. & Dead twigs or wood & 70 \\
& Dead leaves & $32,37,65$ \\
Prunus sp. & Dead wood & 73 \\
Carya illinoinensis (Wangenh.) K.Koch. & & $18,25,42,44,59,85$ \\
Laurus nobilis L. & Dead wood & 64,93 \\
Rubus ulmifolius Schott. & Dead wood & 20,80 \\
Acanthus mollis L. & Dead twigs or branches & 31,47 \\
Ailanthus altissima L. & Leaves & 68,86 \\
Eriobotrya japonica (Thunb.) Lindl. & Bark of living tree & 28 \\
Fraxinus angustifolia Vahl. & Leaf litter & 76 \\
Hedera helix L. & Bark of living tree & 12 \\
Hibiscus rosa-sinensis L. & Leaves & 89 \\
Pinus halepensis Mill. & Dead bark & 5 \\
Moss & Leaf litter & 46 \\
Ganoderma lucidum (fungus) & Hymenial surface & 54 \\
\hline
\end{tabular}

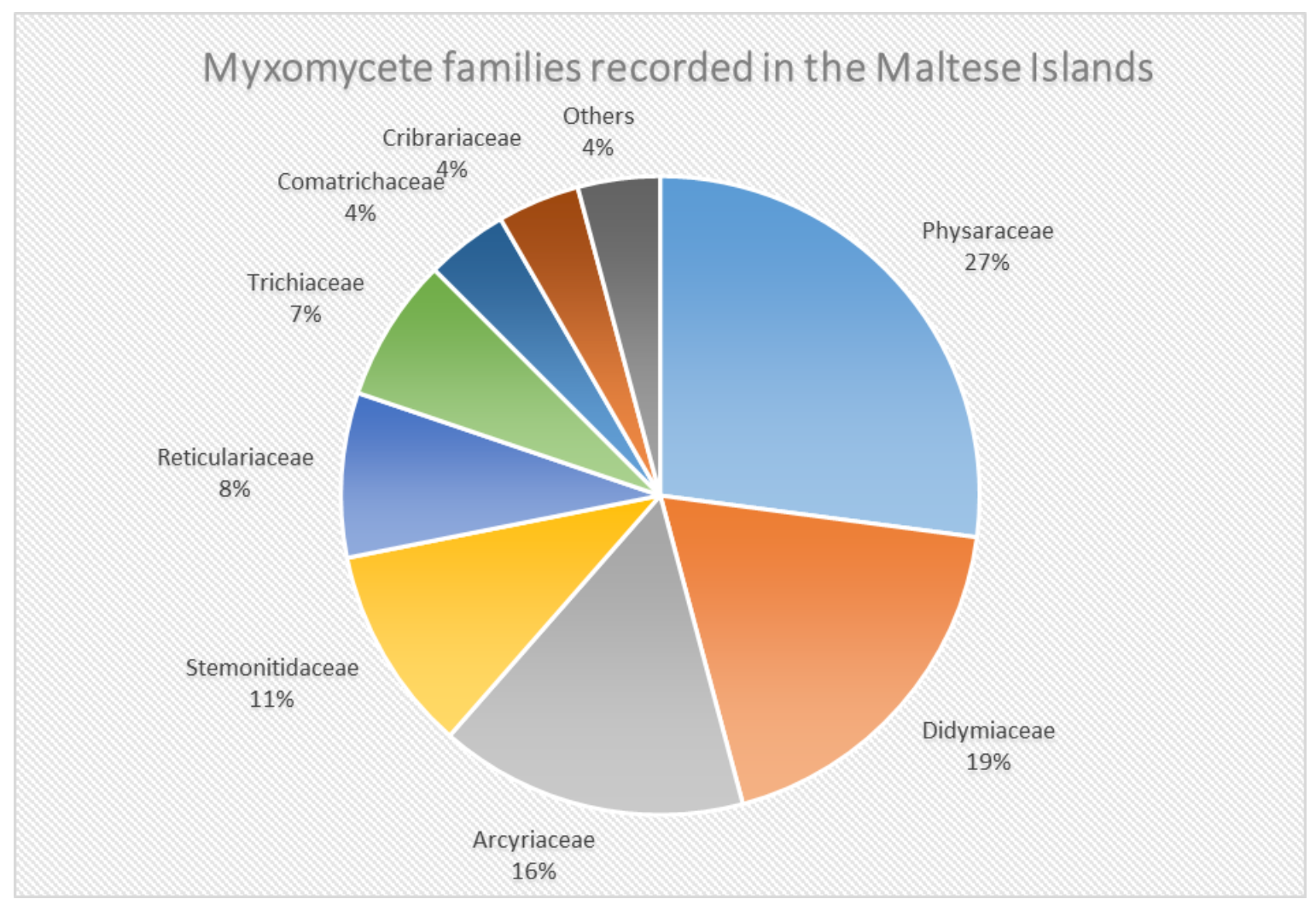

Fig 1. Distribution of families of Myxomycetes in the Maltese islands. 


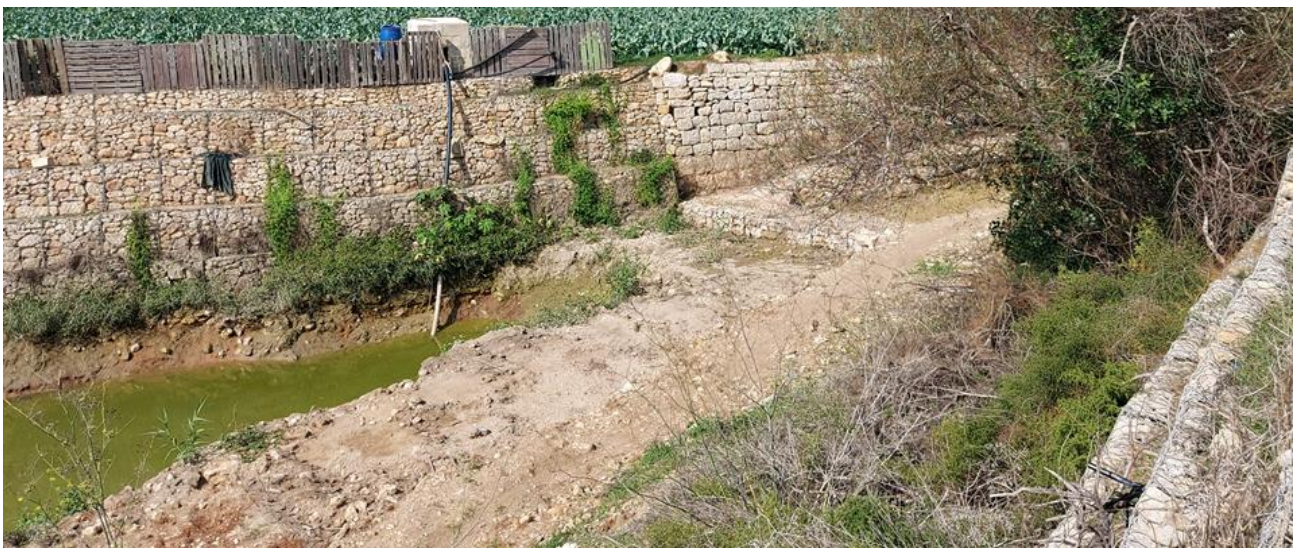

Fig 2. Valley bed and understory scraped off in a valley rehabilitation project at Wied il-Fiddien

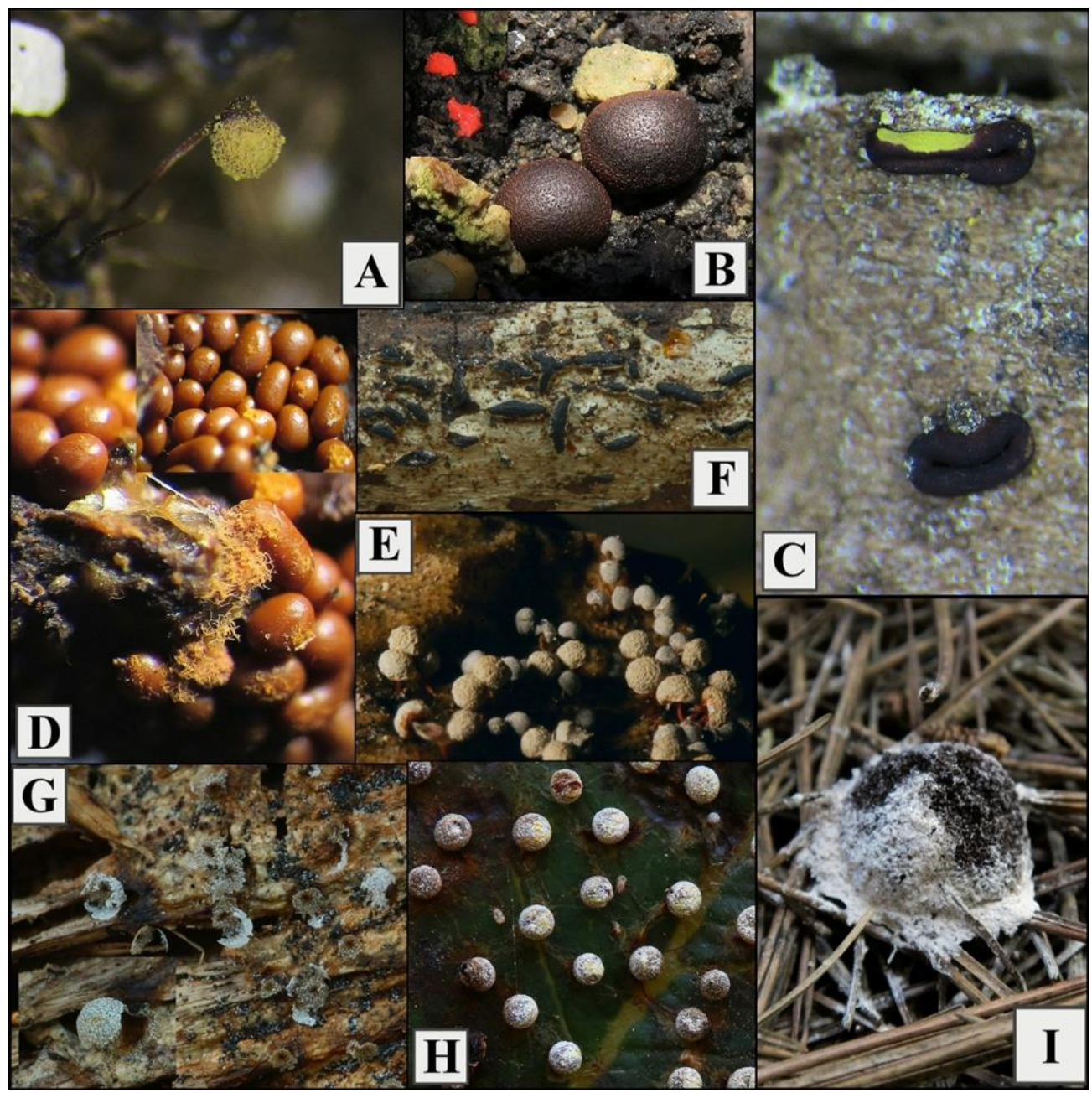

Fig 3. Images of some new records of Myxomycetes from the Maltese Islands: 1A. Cribaria intricata - Menzja Farm House, Ta' Sannat, Gozo (11/11/2019); 1B. Lycogala confusum - Ulysses Garden, Xewkija, Gozo (02/12/2016); 1C. Perichaena chrysosperma - Wied 1-Imgarr, Ghajnsielem, Gozo (14/02/2019); 1D. Trichia affinis - Wied Bingemma, Nadur, Gozo (15/02/2015); 1E. - Badhamia melanospora - Wied Riћana, Nadur, Gozo (11/01/2018); 1F. Perichaena vermicularis - Wied 1-Imgarr ix-Xini, Xewkija, Gozo (10/12/2017); 1G. - Badhamia panicea Wied 1-Imġarr ix-Xini, Xewkija, Gozo (07/12/2019); 1H. Craterium aureonucleatum - Wied Biljun, Qala, Gozo (31/01/2019); 1I. Fuligo intermedia - Ballut tal-Wardija, San Pawl il-Baћar, Malta (23/10/2017). 


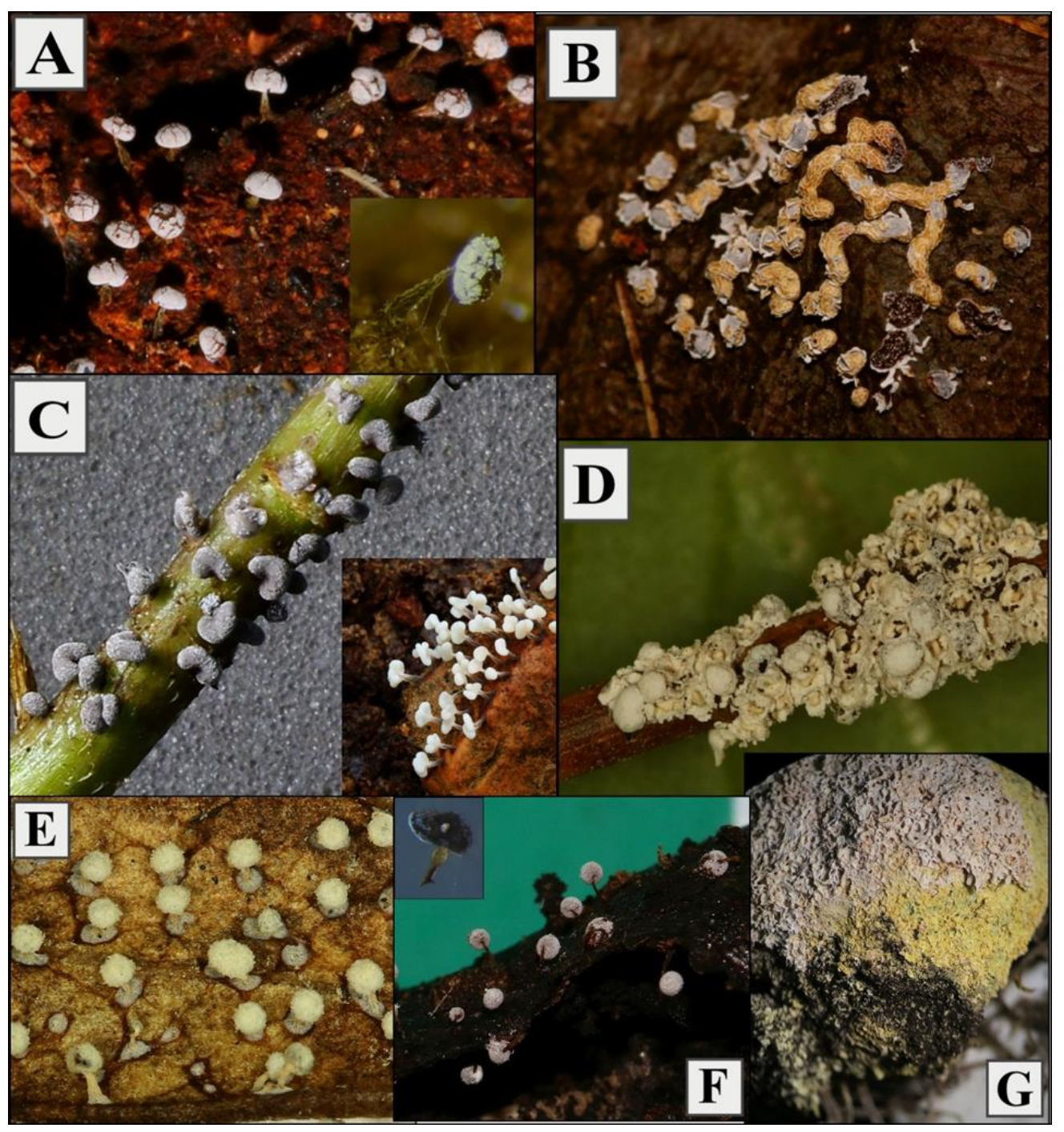

Fig 4. Images of some new records of Myxomycetes from the Maltese Islands: 2A. Physarum album - Wied il-Lunzjata, Kercem, Gozo (15/01/2019); 2B. Physarum plicatum - Wied l-Imġarr ix-Xini, Xewkija, Gozo (01/12/2019); 2C. Physarum straminipes - Ulysses Garden, Xewkija, Gozo (02/12/2016); 2D. Diderma cingulatum - Wied Bingemma, Nadur, Gozo (12/03/2019); 2E. Didymium macrospermum - Wied Bingemma, Nadur, Gozo (12/03/2019); 2F. Didymium verrucisporum

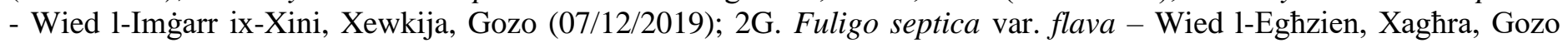
(27/9/2020), first recorded from il-Buskett, Sigggiewi, Malta (30/9/2014) but no close-up photos are available of this record.

Another important aspect is that a few species recorded in Malta are first records for Europe or the Mediterranean region (Briffa 1998; Briffa et al. 2000). Due to their geographic position, the Maltese Islands act as biome bridges with North Africa and Eastern Europe. Populations of some myxomycetes may extend from the eastern Mediterranean region or the African continent up to Malta, making it an important station for the diversity of cryptogams at an European level.

\section{Conclusions}

The checklist of myxomycetes of the Maltese Islands has been updated from 74 records (Briffa 1998; Briffa et al.
2000) to 96 records from six years of fieldwork by the present author. This updated checklist is the first step of an ongoing project to research and narrow the knowledge gap of myxomycetes on the Maltese Islands, after the sterling work that Michael Briffa commenced the at the end of the 20th century. The study reported here is not based on any intensive fieldwork, but more or less ad-hoc visits or encounters during botanical or mycological surveys. More focused surveys and studies would surely reveal more species of myxomycetes in the Maltese Islands and hopefully capture the attention of stakeholders so that the habitat of vulnerable species are protected. 


\section{References}

Borg J (1927) Descriptive flora of the Maltese Islands: including the ferns and flowering plants. Government Printing Office, Malta.

Briffa M (1998) First Checklist of the Myxomycetes of Malta. Xjenza 2(2): 28-34.

Briffa M, Moreno G, Illana C (2000) Some rare Myxomycetes from Malta. Stapfia 73: 151-158.

Grech Delicata JC (1853) Flora Melitensis, sistens stirpes phanerogamas in Melita insulisque adjacentibus hucusque detectas, secundum systema Candolleanum digestas. Melitae.

Kretzschmar M, Kuhnt A, Bonkowski M, Fiore-Donno AM (2015) Phylogeny of the highly divergent Echinosteliales (Amoebozoa). Journal of Eukaryotic Microbiology, 63(4): 453-459 https://doi.org/10.1111/jeu.12289

Link JHF (1833) Handbuch zur Erkennung der nutzbarsten und am häufigsten vorkommenden Gewächse 3. Ordo Fungi, Subordo 6. Myxomycetes 405-422, 432-433. Berlin.

Martin GW, Alexopoulus J (1969) The Myxomycetes. University of Iowa Press.

Mifsud S (2017a) Contribution to the Mycobiota and Myxogastria of the Maltese Islands Part 12014 2016. Micologia Vegetazione Mediterannea, 32(1), $3-58$.

Mifsud S (2017b) Additions of mycobiota and myxomycetes of the Maltese Islands. Bulletin of the Entomological Society of Malta, 9, 99.

MycoBank (2004-2020) Mycobank database Fungal Databases, Nomenclature \& Species Banks. http://www.mycobank.org

Poulain M, Meyer M., Bozonnet J (2011) Les Myxomycètes. FMBDS - Fédération mycologique et botanique Dauphinée-Savoie, Sevrier, France.

Saccardo PA (1912) Fungi ex Insula Melita (Malta), lecti a Doct. Alf. Caruana Gatto et Doct. Giov. Borg. Bulletino della Societa Botanica Italiana, 314-326

Saccardo PA (1914) Fungi ex Insula Melita (Malta) lecti a Doct. A. Caruana-Gatto et Doct. G. Borg annis MCMXIII, serie II. Nuovo Giornale Botanico Italiano, 21, 110-126.

Saccardo PA (1915) Fungi ex Insula Melita (Malta) lecti a Doct. A. Caruana-Gatto et Doct. G. Borg annis MCMXIII et MCMXIV, serie III. Nuovo Giornale Botanico Italiano, 22, 24-76.

Sommier S, Caruana Gatto A (1915) Flora melitensis nova. Stabilimento Pellas, Firenze.

Stephenson SL, Schnittler M (2017) Myxomycetes. In: Archibald, J., Simpson A., \& Slamovits, C. (Eds.)
Handbook of the Protists. Springer Cham. (pp: 1405-1431). 